Solution of Parapolic Navier-stokes Equations for laminar Forced Convective flow in Entrance Region of a Flat fassage

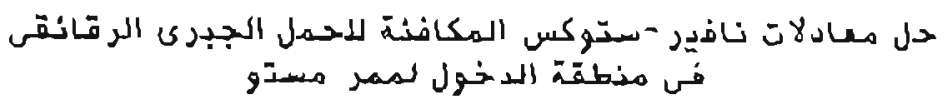

M. G. WRSEL

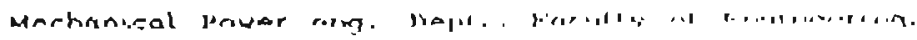

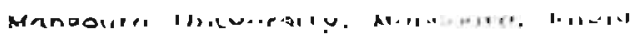

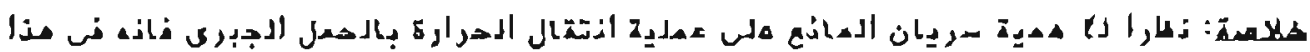

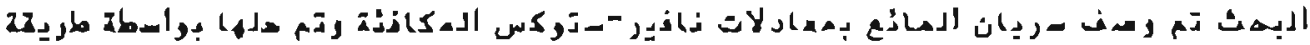

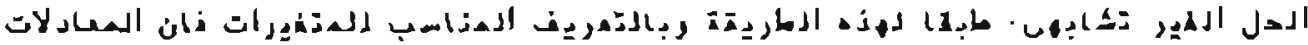

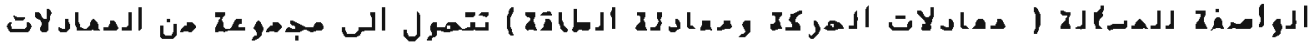

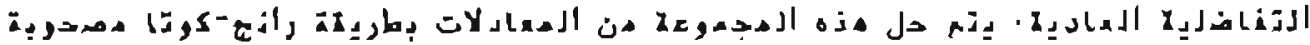

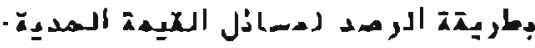

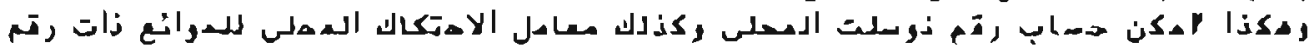

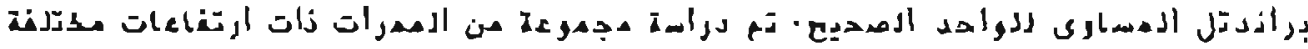

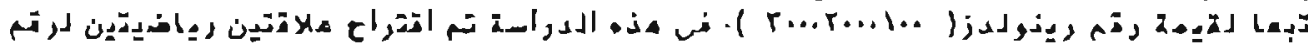

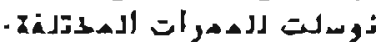

Abstract- Due to dependence of forces corvectlve leat transfer on the hydrodynamL Elow Eleld; any Inprovement on the analysis of this flow fleld ls of great Importance to understand the heat transerer process. In this work the clow fleld ls descrlbed by the parabollc Navier-stokes equalions; which are solved by local non-simllarity solutlon-method. According to this method; with cultable definition of the problem variables, a set of ordinary differential equations are produced. This set is solved, numerically, by Runge-kutta method accompanies dilh shouling nethud of boundary value problems.

The values of local Nussell rumber and local coefelclent of criction are calculated for flulds of pranoti number of ore. Some passages of Reynolds number(Re, of 100 , 200 \& 300 are studled here. Two formulat of Nussell numbi for different passage heighls ale prupuited.

1. Introductlon

Good understanding of convectlve heat transfer oroblems is dependent, principally, su goud analysly of the hydrodynamic flow field. The developerient of hydrudynamic flow flejo in combined entrance ceyiur of a duct vas sludiuj by gany investigators. Kakdt all] Yener 〔2\} uurveyed dieferent methods developed lo solve the problen of lasinar Eorced convection in combined entrance region of a duct. Hasel [4] made a local slnillarlty solution of lamlnac forced convection in entrance reglon for flow belween two parallel plates. 
In those works, the hydrodynamic Elod Eleld was descrlbed by boundary layer equatlons. Recently, wasel (5) made a solution of the flow Eield based on the parabolic Havier-stokes equations [11. Accorolng to lie used method In hls solution some terms in modified governing equations were dropped. In present work, an imurovement of hls solution is made by solving the governing equations of the problem by local non-similarity solution method (3). Because of the nature of the governing equations and of the uste lechnique, the solution is carried out in step by step manner.

\section{Governing Equationg}

As shown In Flg. (1) the lamindr flow betreen two garallel Elat plates is considered. The unlform velocity of approach, the temperature and eressure at irlet uf the

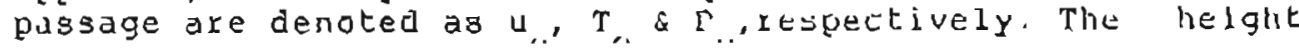
of the passage is taken as $2 b$. Hall temperature $\left(T_{v}\right)$ is assumed to be constant. constant elula pruperties are assumed.

The governing equations can be wrltten in cartesian co-ordinate $x, y$ as follows:

$$
\begin{aligned}
& \frac{d u}{3 x}+\frac{3 v}{3 y}=0,
\end{aligned}
$$

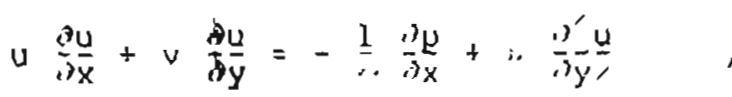

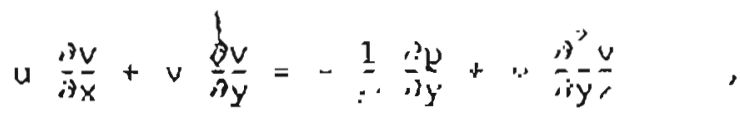

$$
\begin{aligned}
& \mathrm{u} \frac{\partial \mathrm{T}}{\partial \mathrm{x}}+\mathrm{v} \frac{\partial \mathrm{T}}{\mathrm{y}}=\alpha \frac{\partial \mathrm{T}}{\mathrm{y}} \mathrm{y}
\end{aligned}
$$

where $u$ and $v$ are the velocity comporients in $x$ - and $y$-directions, respectively, $T$ and $p$ are the temperature and pressure of fluld. $r$, " and " are the density, kinematc viscoslty and thermal dffeuslvity, respelively. The second derivative of $u, v$ and $T$ with respect to $x$ are assumed to be small compared with oth

The velocity proflle at any position $(x)$ must salisfy the continulty eguation in integral form and hence, one can write the equation;

$$
s^{h} \mathrm{u} d y=i u, \text { b. }
$$

nccording to equation (5), the velucity at axis of similarity must be correctea to the proper value, which produces a velocity proflle satisfles this equation.

Due to the simllarlty of lydrodyriamic as well; thermal 
Elelus about the axls of the passage, it ls cunvenlent to solve the governing equations fram one wall to lile center of the passage. Equatlons (1)-(4) possess the following boundary conditions;

$$
\begin{aligned}
& u=v=0 ; T=T_{v} \text { at } y=0,(6-a) \\
& u=u_{r, x} ; \frac{\partial y}{\partial y}=0 ; T=T_{u} \text { at } y=0 .(6-b)
\end{aligned}
$$

To express the governing equations in dimenstonless Eorm, one introduces liew independent varlables;", as Eollows;

$$
\tau=\frac{1}{b} \sqrt{-\frac{x}{u_{0}} \frac{p}{0}} \quad, n=y \sqrt{-\frac{y}{x}} .
$$

Furthermore, a dimenslonless forms of stream function, pressure and temperature are defiried according to the folloving relations;

$$
\begin{aligned}
& \psi(x, y)=\sqrt{00 \times y} \in(Y, y),(8-a) \\
& P(\varepsilon, n)=\left(p(x, y)-p_{.}\right), 1 u^{*}, \quad(8-b) \\
& \theta(\ddot{\zeta}, i)=\left(\mathrm{T}-\mathrm{T}_{0}\right) /\left(\mathrm{T}_{-}-\mathrm{T}_{.}\right),(\theta-c)
\end{aligned}
$$

where $w(x, y)$ is the stream Eunction, which ls defined such that it satiseles the contluuity equation (1). E $(5, n)$, $P(5, n)$ and $(\zeta, n)$ are the dimensionless forms of stream Eunction, pressure and reinperature, rospectively. substitution of equations $(7)-(8)$ into equations (2)-(4) leads to the following dimensionless form uf governing equationg, (wilere the primes denoting Jikferentiation with respect to $n$ and the sutelx; denoting the differentation Ultil respect to $\xi)$ :

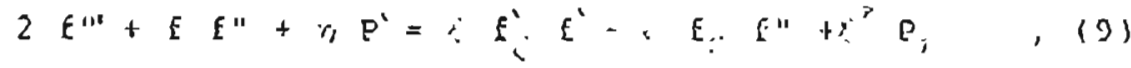

$$
\begin{aligned}
& 2 \eta E^{\prime \prime}+2 E^{\prime \prime}+\eta E E^{\prime \prime}+E E^{\prime}-" E^{\prime}-4 Y^{\prime} R e_{1}^{2} P^{\prime}=
\end{aligned}
$$

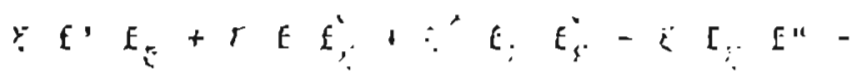

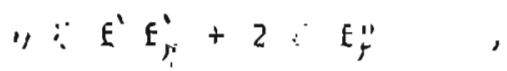

$$
\begin{aligned}
& \frac{2}{\mathrm{P}} \mathrm{Q}^{\prime \prime}+\left(\mathrm{E}+\zeta \mathrm{E}_{\zeta}\right) ;-i \mathrm{E}^{\prime} i_{i}=0,
\end{aligned}
$$

where Re is the Reynolas number based on the half of the passage helght and deflned as $R_{n}=u_{0} b / x$ 
Deflning $G$ as the derlvatlve of $f$ with respect to r and neglecting $E_{\xi}$ from equation(g), one can elemiliate $p$ from equations (9)-(20). The produced equation is uritten in gimple appearance as follows:

$$
a_{1} E^{\prime \prime}+a_{2} E^{\prime \prime}+a_{3} E^{\prime}+a_{1} E+a_{a}=0,(12-a)
$$

where $a_{1}, a_{2}, a_{a}, a_{4}$ and $a_{: 3}$ are coefelelents intorduced to put the obtalned equation in simbler appearance. These coefficlents have the Eollowing deflnitlons;

$$
\begin{aligned}
& a_{1}=8 \xi^{2} R e_{1}^{2}+2 n^{2}
\end{aligned}
$$

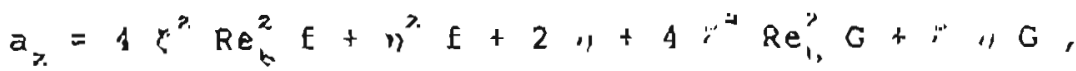

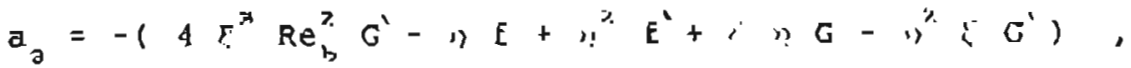

$$
\begin{aligned}
& a_{b}=-5 i G^{\prime} \\
& a_{s}=-\left(\xi^{2} \cap G G^{\prime}+2 \xi \text { in } G^{\prime \prime}\right)
\end{aligned}
$$

Accordind to the used technlgue of solution ( local non simllar solution-method (3), , the der\{vative of $t$ with respect to $\%$ is dealed with as a new dependent varlable (G) and thus one needs another subsidiary equation. This equation can be obtalned by defferentiating equation with respect to $\xi$. The produced equation takes the following form;

$$
b_{1} G^{\prime \prime}+b_{2} G^{\prime \prime}+b_{7} G^{\prime}+b_{\perp} G I b_{7}=0 \text {, }
$$

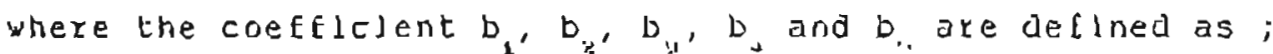

$$
\begin{aligned}
& b_{1}=a \sum^{2} \operatorname{Re}_{b}^{2}+2 \% \text { (13-b) } \\
& b_{2}=4 R_{b}^{7} f+n^{7} t+1 r^{7} \operatorname{Re}_{b}^{7} G+r \because G, \quad(13-c)
\end{aligned}
$$

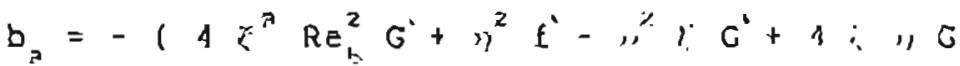

$$
\begin{aligned}
& \left.+12 i^{\prime} \mathrm{Re}_{\mathrm{i}}^{2} \mathrm{E}^{\prime}\right) \\
& b_{4}=16 \xi^{2} \operatorname{Re}_{h}^{2} \mathrm{E}^{\prime \prime}+r^{7} \mathrm{E}^{\prime \prime}+\eta \mathrm{C}^{*}
\end{aligned}
$$

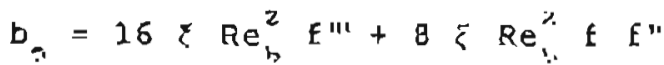

According to the definltion of $G$ and by neglecting the derlvat lve of $\theta$ with respect to ", the energy equation(11) takes the following form; 


$$
\frac{2}{P L} \hat{O}^{\prime \prime}+(\mathfrak{E}+\because \sigma) \hat{\theta}=0 .
$$

Equations (12)-(14) repcesent a syster of ordinary differential equations in $t, G$ and $n$ as unkowis and $k$ is dealed with as a parameter. Thls systen of equations has the tollowling boundary condltions;

$$
\begin{aligned}
& E=E^{\prime}=G=G^{\prime}=0 \quad ; \quad \hat{y}=1 \quad \text { at } ;=0, \\
& E^{\prime \prime}=G^{\prime \prime}=\emptyset=0 ; \quad E^{\prime}=u_{O, x} / u_{1,} \text { at } \because=\eta_{1} .,
\end{aligned}
$$

where f'at $\eta$, has to produce a veloclty pxofile satiseles the following condition;

$$
\int_{n}^{\eta} e^{\prime} d_{\prime \prime}=" 1
$$

where $\eta_{b} 15$ the value of the varlable " at the center of the passage $\left(n_{t}=b \sqrt{u_{0} / n^{x}}\right.$ ). Equation $(15-c)$ is derived usling the definltions of dimensionless vaclables; equations $(7-B)$ \& equation (5).

3. Numerlcal Procedure

According to the local non-similarity melliod 131 , the modifled governing equations (12)-(15) are solved for different values of the parameter $\xi$. As it is clear from equation ( 7 ) the value of $\left\{\right.$ can be expressed lin lerms of $n_{\text {N }}$ $\left(F=1 / \eta_{b}\right)$, thus the solution of the governing equations is carcled out several tlmes for different values of " and In turn; for different values of

In case of torced conveclive flow, lhe momentum equations (22)-(13)\& (15) can be solved separately and then the solution of energy equation (14) can be carrled out. For certaln value of $\xi$, the mumerical solution is carried out through two maln steps. First; lic consldered equations $(12-13 \& 15)$ are solved tur assumed values of $E^{\prime \prime}(0) \&$ $G^{\prime \prime}(0)$ by Runge-kutta method of ordinary differential equations ano then the solution is corrected by shooting method of boundary value probleras to satisfy the boundary conditlons at $n=n_{n}\left(E "\left(n_{1}=G "\left(n_{1}\right)=0\right)\right.$. Second step; is to correct the obtalned velocity proflie (f versus "y) to satisey the equation $(15-c)$. This is achieved by using shooting method for second time.

Knoulng the value of $E$ \& $G$ for different valueg of $\because ;$ as It is done before, the energy equatioll and its boundary conditions equations $(11)-(15)$ can be solved in sirilar manner.

When the flelus of veloclty and temperature have been 
obtalned, local Nusselt number (Nu,) and local coefelclent of friction ( $C_{f}$ ) can be determined according to the following deflnitlons;

$$
\begin{aligned}
& \left.\tau_{v}=\rho, \frac{\partial u}{\partial y}\right)_{y=0}, \\
& \left.q_{v}=h\left(T_{v}-T_{0}\right)=-k \frac{\partial T}{\partial y}\right)_{y=0},
\end{aligned}
$$

where $g_{w}$ is the heat flux at single plate of the two heated plates. Introducing the almenslonless varlables in equat lons (16)-(17), one obtalos the folloulng expressions of local Nusselt number and local coefficlent of Eriction:

$$
\begin{aligned}
& N u_{x} / \sqrt{R e}_{x}=\partial \cdot(r, 0), \\
& C_{1}^{\prime} \sqrt{\operatorname{Re}_{x}}=\xi^{\prime \prime}(1 ;, 0)
\end{aligned}
$$

where Re, denotes the local Reynolds number $(u, x / v\rangle$ and Nu is local Nusselt number ( $h x / k)$.

\section{Results and Discussion}

The calculations are carrled out for three different passage helghts according to the value of $R_{1},\left(u_{2} b / 1\right)$ equals to $100,200 \& 300$. Tlirough these calculations the flulds of Pr $=1.0$ is consloered.

Flg. (2) shows the relation between local coefflcient of Erlction and local Nusselt number as defiried in equations (18)-(19) versus the dimensionless distance along tie passage represented by $\zeta$. It la clear that no efeect of gassage helght on the value of coefficlent of Eriction at values of $\{>0.15$. For Nusselt number, in the sume Elgure in general, the helght of passage has no eflect or at least very small effect through out the studled range of $\because$. consequently it ls convenlent to derive a formula for

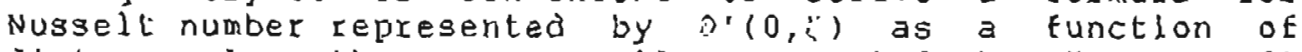
distance along the passage wall represented by $F$. Fig.(3) shows two proposed formulae compared wilh the calculated data points. They, mathematlcally, are expressed in the two following relations as;

$$
\begin{array}{ll}
\Delta^{\prime}=0.302836 \tau+0.338300 & \text { (lineax Eit) } \\
\Delta^{\prime}=0.340181 \text { Exp }\left(0.782064 \zeta_{\text {s) }}\right. & \text { (exponential EIt) }
\end{array}
$$

According to the deflnition of Nusselt namber as well; coefficlent of friction equations (1B)-(19) and other varlables of the problem, one can obtain new relations after some manlpolations of the obtalned numerlcal results ( $x^{4} \&$ f" versus $\bar{\zeta}$. Flg.(4) shows the rLlations between $\mathrm{Nu}_{x}$ and the dimensionless distance along the passage $\left(\left\langle(x / b) / R_{t}\right.\right.$ Pr 1 . 
Nusgelt number (Nu, Increases rapldly near the entrance of the passage.then it Increases linearly for greater oistance. Flg. (5) shows local Nusselt number based on the half of passage helght $\left(\mathrm{Nu}_{b}=\mathrm{h} \mathrm{b} / \mathrm{k}\right.$ ) vexsus $\mathrm{binensionless}$ distalle along the plate $(x / b)$. Near the entrance of the passage Nuh has very large values and suddenly drops and goes to asynptotlc values (as it is clear in case of $\operatorname{Re}_{1:}=300$ ). Fig.(6) shows local coefelclerit of filction versus dimensionless alatance $(x / b)$ for alfferent values of passage helghts. For narrow paszage (Re $=100$ ) the value of coefelclent of friction ls greater.

\section{Conclusion}

the uged technique in present work, presents a slmple passlbie way to deal sufflclently vith parabolic Navlex-stokes equations. In the same time, this technique is sultable to be lased to solve the energy equatlul. According to the proper trangformation of the varlableg of problem. two proposed formulae for estimating Nusselt number of considered problen are presented here.

6. Nomenclature

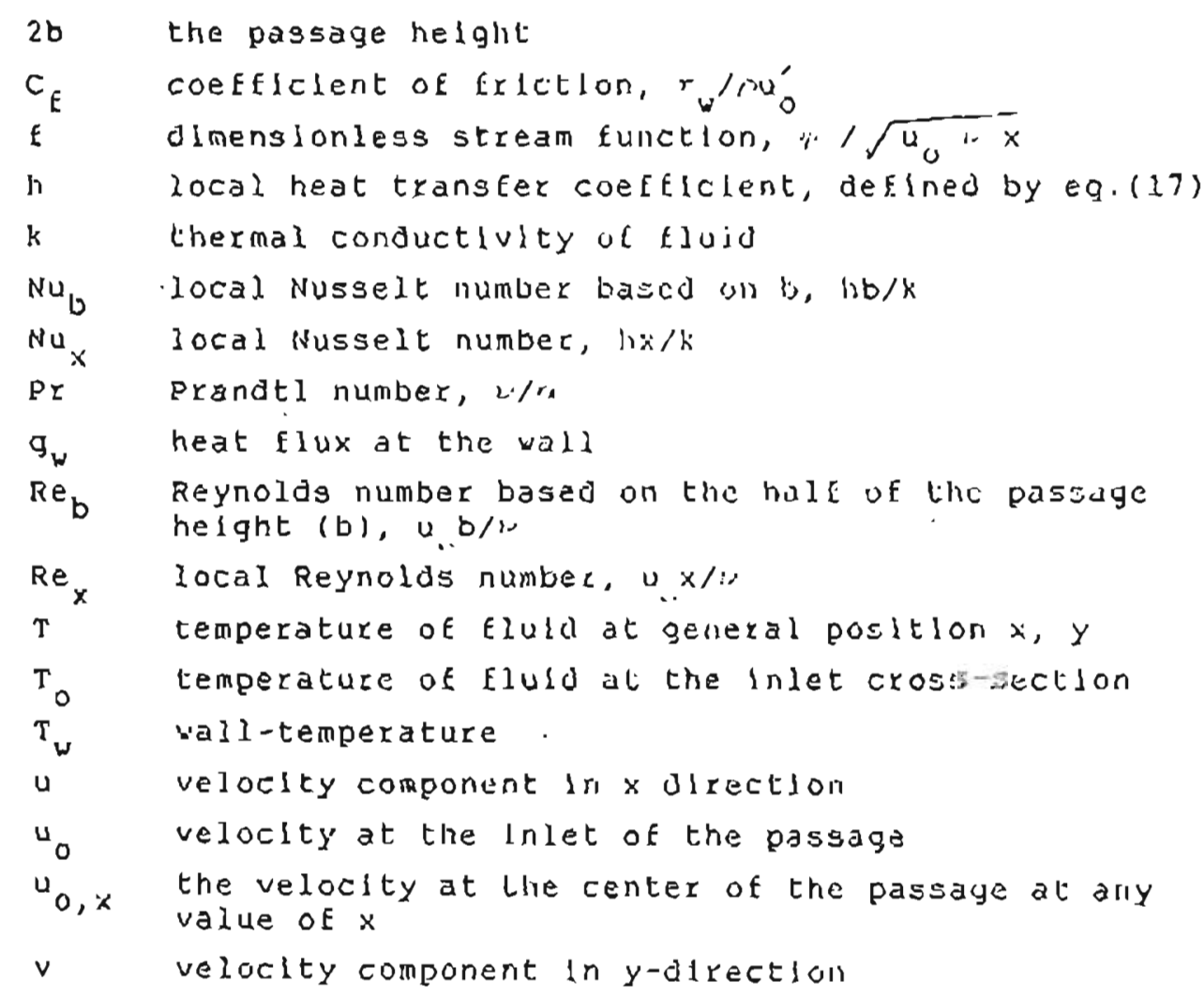


M. 67 M.G. IVA.SEL

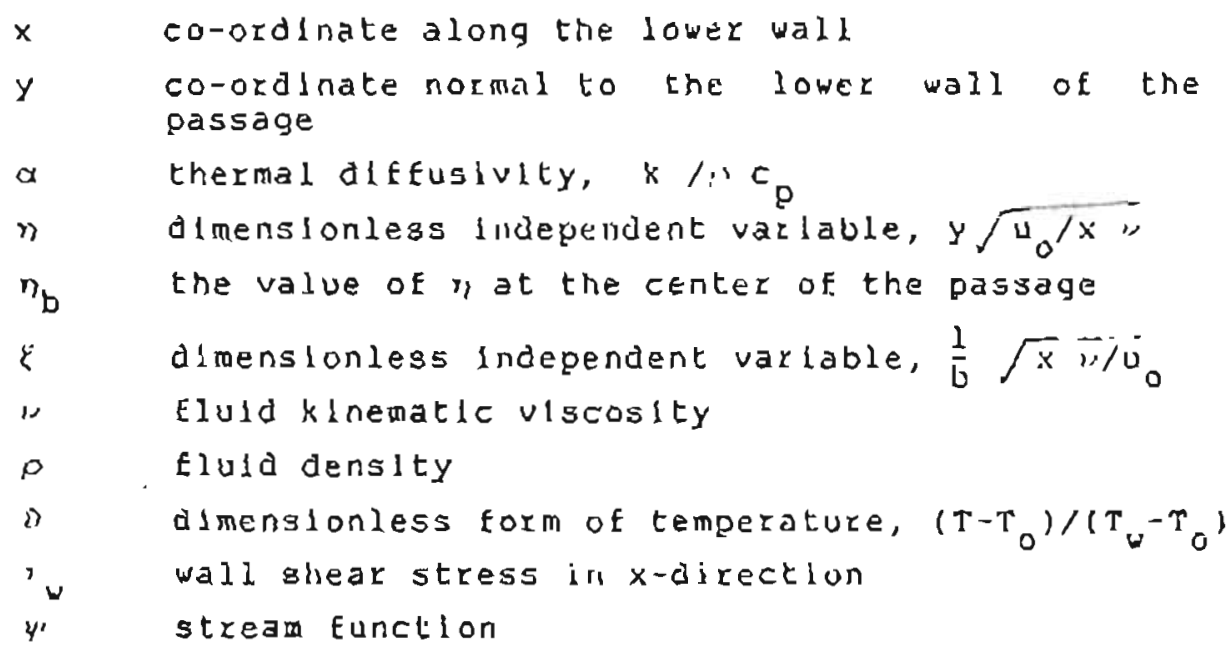

7. Refrences

1. S. U. Patankez, D. B. Spaluing, $\Lambda$ colculation procedure tor heat, mass and momentum transler lil threemolmenslonal garabolic flov, $J$, heat sasa Transfer, Vol. I5, gp. 1787-1806,1972

2. S. Kakac, Y. Yencr, Lamlnax Eorced collvection in comblned entrance xeglon of ducts, slou Reynolds number flow in heat exchangers, (Ed. Kakac, Shahs Bergles\}, pp. 165-201, Hemispliere, 1388.

3. E. M. Sparrow, H. Quack and C. J. Eoerner, Local non-slmilarity boundary dayer Eolutions, AIAA Journal, vol. 8, No 11, pp. 1936-1942, 1970

4. M. G. Wasel, Local stmilarlty solution of laminar forced convection in entrance reglon for flow betueen two parallel plates, HEJ, vol, 19, No. 1, June 1989.

5. M. G. Wasel, solution of varabolic Navier-stopes equatlons for the entrance region-flow between two paraldel plates, MEJ, Vol. 16, \$10. 1, June 1991. 


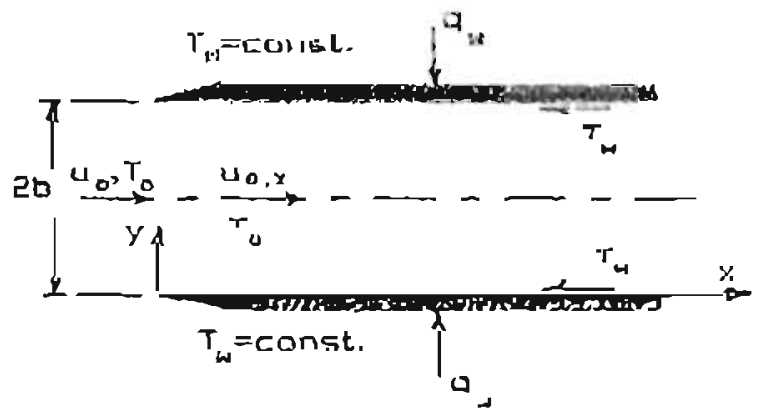

Fig. (1) Sçhema:ic viescrididisn oi the llow thirough the passigge.

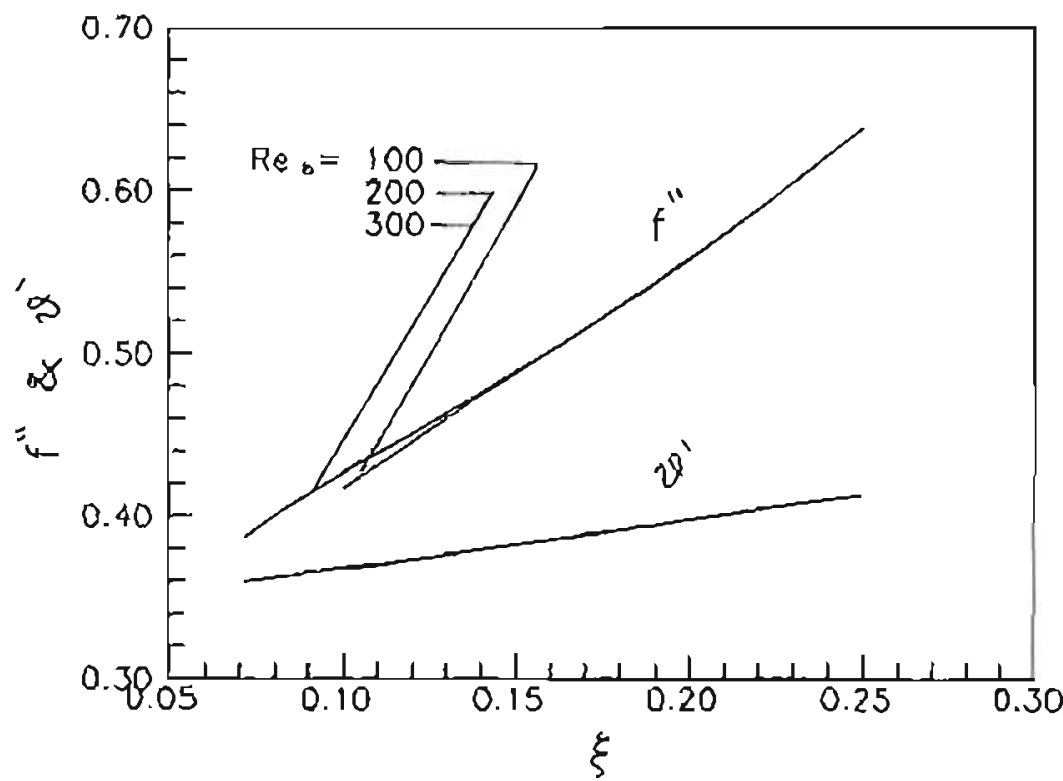

Fiq. (2) Nussell number ond coelficient of triction os defined in equotions (18\&19) versus the dimensionless distonce $\xi$ for Re s equals $10 \quad 100,200 \& 300$. 
W. 69 N.C. WASEL

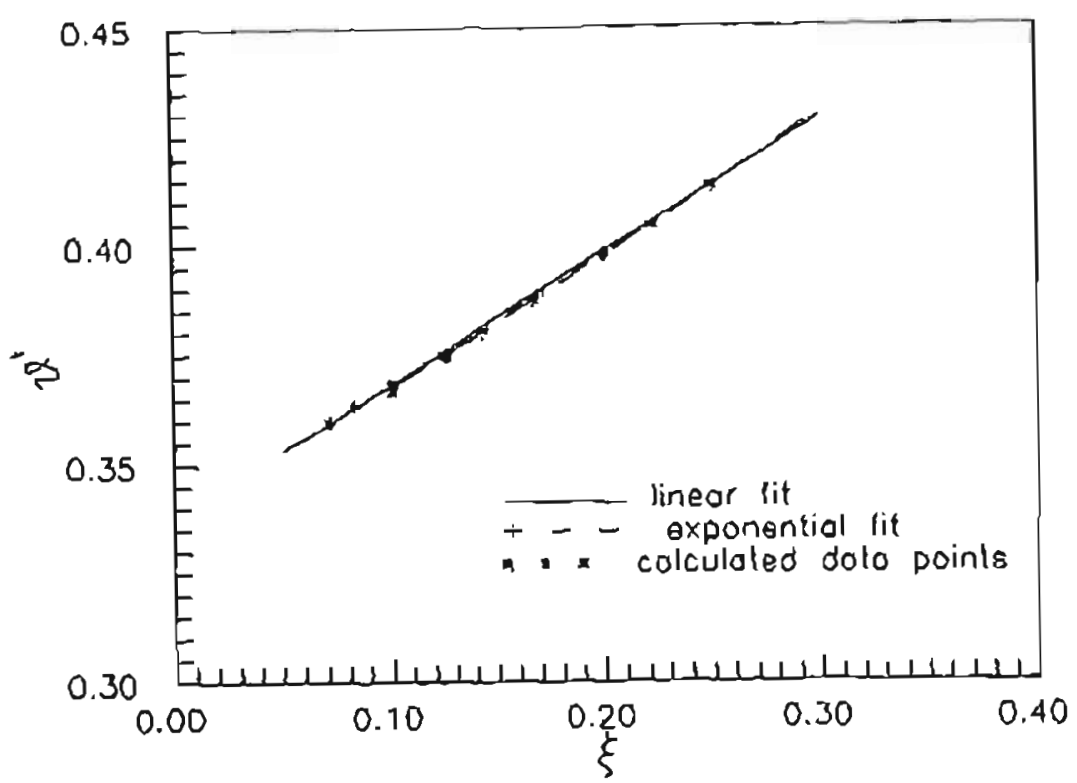

Flg.(3) The colculated Nusselt number as defined in equation (18) compared with lineor ond exponentiol regression.

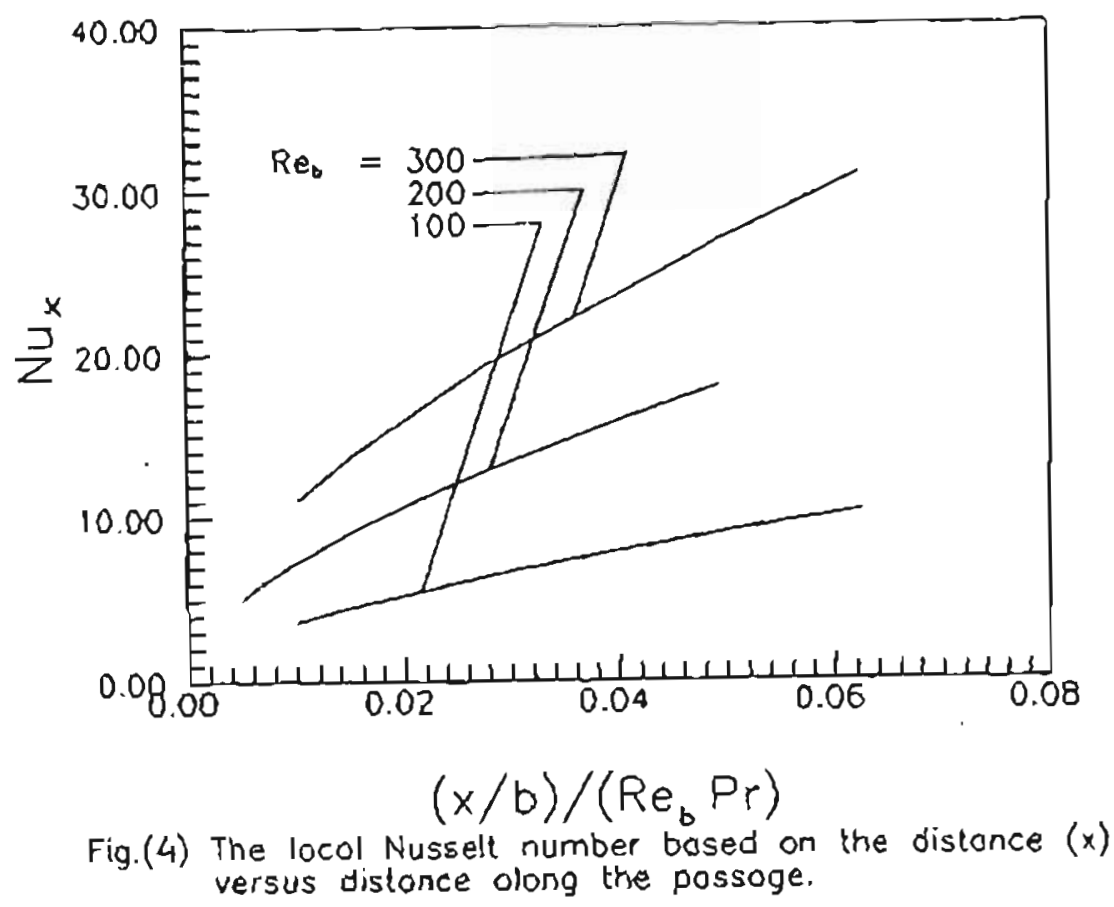




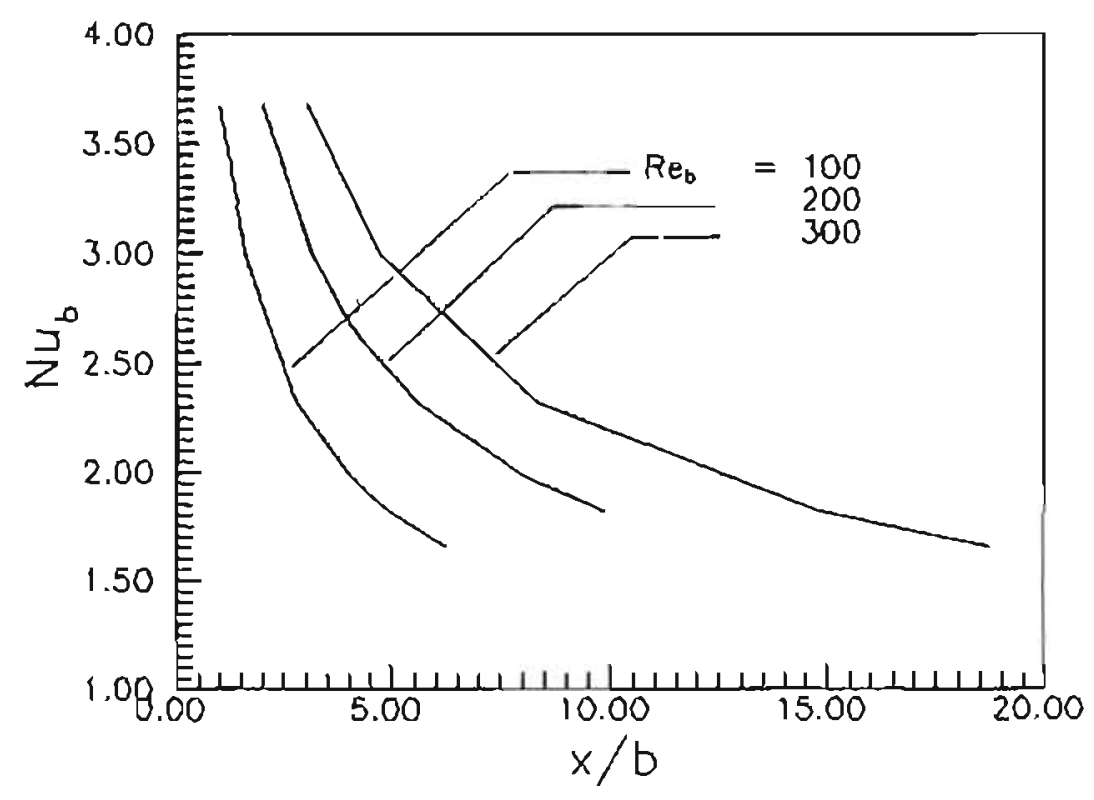

Fig.(5) Nusselt number bosed on the half of the passage height versus distance along the possoge.

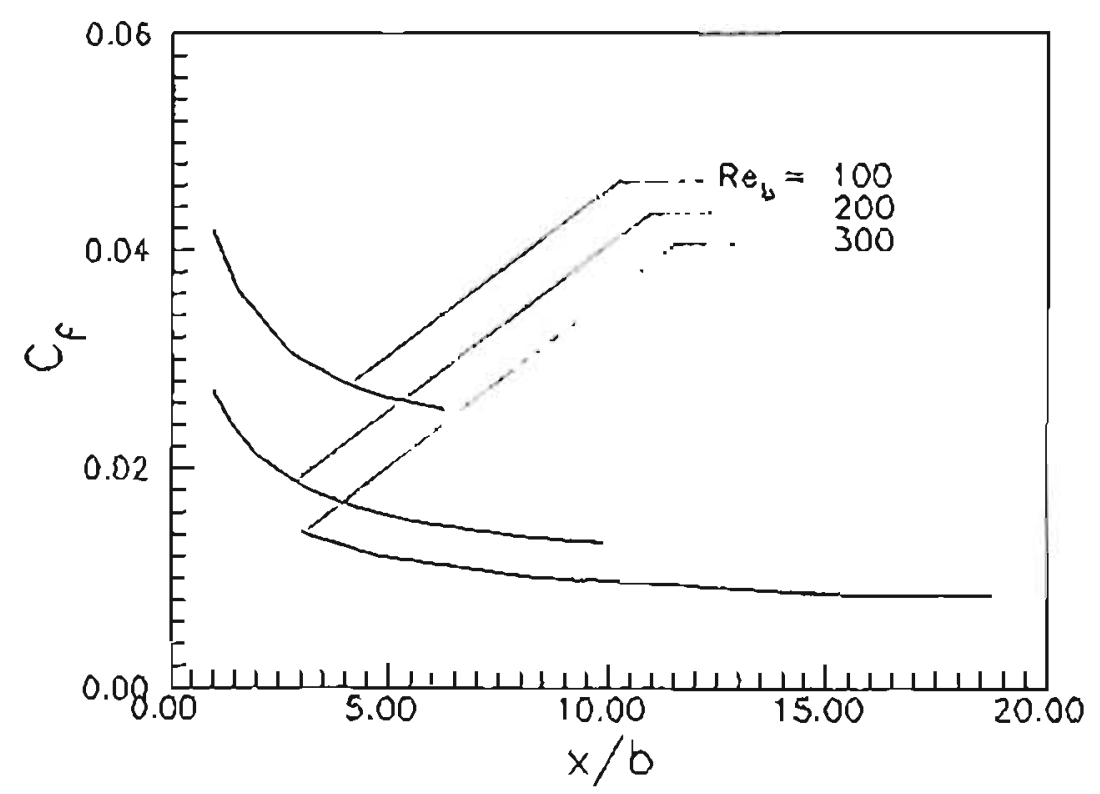

Fig. (6) The coefficient of friction along the possoge lor different possoge height. 


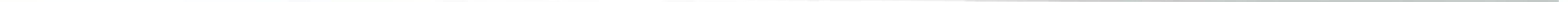

